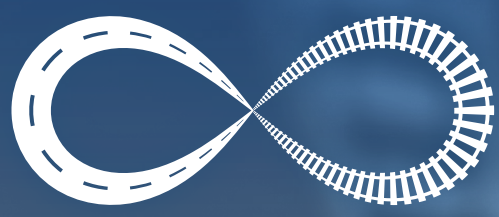

CETRA $^{2018}$

$5^{\text {th }}$ International Conference on Road and Rail Infrastructure 17-19 May 2018, Zadar, Croatia

Road and Rail Infrastructure V

Stjepan Lakušić - EDITOR

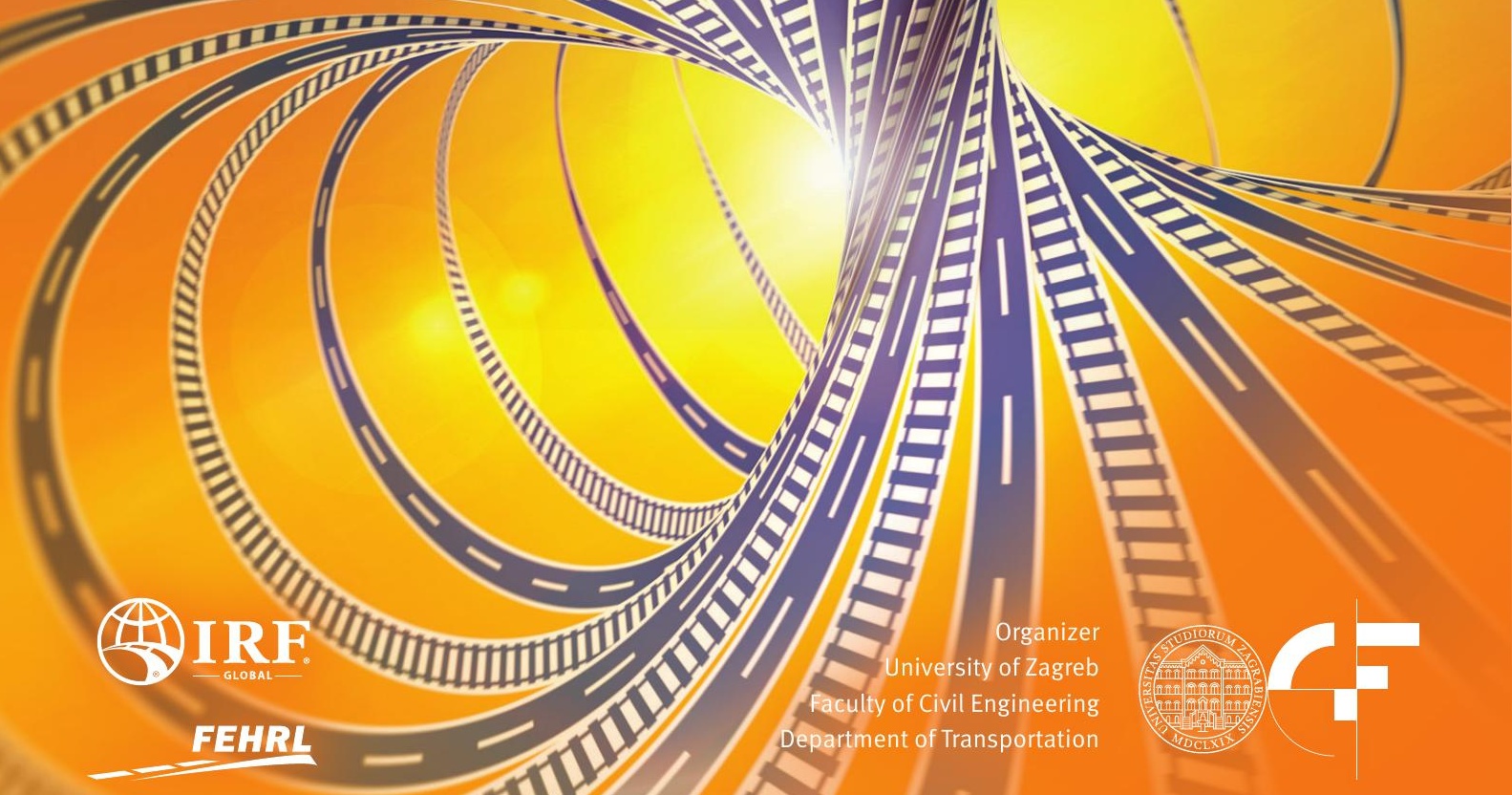




\section{CETRA $^{2018}$}

\section{$5^{\text {th }}$ International Conference on Road and Rail Infrastructure 17-19 May 2018, Zadar, Croatia}

TITLE

Road and Rail Infrastructure V, Proceedings of the Conference CETRA 2018

EDITED BY

Stjepan Lakušić

ISSN

$1848-9850$

ISBN

978-953-8168-25-3

DOI

10.5592/CO/CETRA.2018

PUBLISHED BY

Department of Transportation

Faculty of Civil Engineering

University of Zagreb

Kačićeva 26, 10000 Zagreb, Croatia

DESIGN, LAYOUT \& COVER PAGE

minimum d.o.o.

Marko Uremović · Matej Korlaet

PRINTED IN ZAGREB, CROATIA BY

“Tiskara Zelina”, May 2018

COPIES

500

Zagreb, May 2018.

Although all care was taken to ensure the integrity and quality of the publication and the information herein, no responsibility is assumed by the publisher, the editor and authors for any damages to property or persons as a result of operation or use of this publication or use the information's, instructions or ideas contained in the material herein.

The papers published in the Proceedings express the opinion of the authors, who also are responsible for their content. Reproduction or transmission of full papers is allowed only with written permission of the Publisher. Short parts may be reproduced only with proper quotation of the source. 
Proceedings of the

$5^{\text {th }}$ International Conference on Road and Rail Infrastructures - CETRA 2018

17-19 May 2018, Zadar, Croatia

\section{Road and Rail Infrastructure V}

\section{EDITOR}

Stjepan Lakušić

Department of Transportation

Faculty of Civil Engineering

University of Zagreb

Zagreb, Croatia 
CETRA $^{2018}$

$5^{\text {th }}$ International Conference on Road and Rail Infrastructure

17-19 May 2018, Zadar, Croatia

\section{ORGANISATION}

\section{CHAIRMEN}

Prof. Stjepan Lakušić, University of Zagreb, Faculty of Civil Engineering

Prof. emer. Željko Korlaet, University of Zagreb, Faculty of Civil Engineering

ORGANIZING COMMITTEE

Prof. Stjepan Lakušić

Prof. emer. Željko Korlaet

Prof. Vesna Dragčević

Prof. Tatjana Rukavina

Assist. Prof. Ivica Stančerić

Assist. Prof. Maja Ahac

Assist. Prof. Saša Ahac

Assist. Prof. Ivo Haladin

Assist. Prof. Josipa Domitrović

Tamara Džambas

Viktorija Grgić

Šime Bezina

Katarina Vranešić

Željko Stepan
Prof. Rudolf Eger

Prof. Kenneth Gavin

Prof. Janusz Madejski

Prof. Nencho Nenov

Prof. Andrei Petriaev

Prof. Otto Plašek

Assist. Prof. Andreas Schoebel

Prof. Adam Szeląg

Brendan Halleman

INTERNATIONAL ACADEMIC SCIENTIFIC COMMITTEE

Stjepan Lakušić, University of Zagreb, president

Borna Abramović, University of Zagreb

Maja Ahac, University of Zagreb

Saša Ahac, University of Zagreb

Darko Babić, University of Zagreb

Danijela Barić, University of Zagreb

Davor Brčić, University of Zagreb

Domagoj Damjanović, University of Zagreb

Sanja Dimter, J. J. Strossmayer University of Osijek

Aleksandra Deluka Tibljaš, University of Rijeka

Josipa Domitrović, University of Zagreb

Vesna Dragčević, University of Zagreb

Rudolf Eger, RheinMain Univ. of App. Sciences, Wiesbaden

Adelino Ferreira, University of Coimbra

Makoto Fujiu, Kanazawa University

Laszlo Gaspar, Széchenyi István University in Győr

Kenneth Gavin, Delft University of Technology

Nenad Gucunski, Rutgers University

Ivo Haladin, University of Zagreb

Staša Jovanović, University of Novi Sad

Lajos Kisgyörgy, Budapest Univ. of Tech. and Economics
Anastasia Konon, St. Petersburg State Transport Univ.

Željko Korlaet, University of Zagreb

Meho Saša Kovačević, University of Zagreb

Zoran Krakutovski, Ss. Cyril and Methodius Univ. in Skopje

Dirk Lauwers, Ghent University

Janusz Madejski, Silesian University of Technology

Goran Mladenović, University of Belgrade

Tomislav Josip Mlinarić, University of Zagreb

Nencho Nenov, University of Transport in Sofia

Mladen Nikšić, University of Zagreb

Andrei Petriaev, St. Petersburg State Transport University Otto Plašek, Brno University of Technology

Mauricio Pradena, University of Concepcion

Carmen Racanel, Tech. Univ. of Civil Eng. Bucharest

Tatjana Rukavina, University of Zagreb

Andreas Schoebel, Vienna University of Technology

Ivica Stančerić, University of Zagreb

Adam Szeląg, Warsaw University of Technology

Marjan Tušar, National Institute of Chemistry, Ljubljana

Audrius Vaitkus, Vilnius Gediminas Technical University

Andrei Zaitsev, Russian University of transport, Moscow 


\title{
MIX DESIGN AND PRELIMINARY VALIDATION OF SUSTAINABLE ASPHALT CONCRETE MANUFACTURED WITH ELECTRIC ARC AND LADLE FURNACE STEEL SLAGS
}

\author{
Marta Skaf', Vanesa Ortega-López ${ }^{2}$, Juan Manuel Manso², Emiliano Pasquini³ \\ Marco Pasetto ${ }^{3}$ \\ 1 University of Burgos, Department of Construction, Spain \\ 2 University of Burgos, Department of Civil Engineering, Spain \\ ${ }^{3}$ University of Padua, Dep. of Civil, Environmental and Architectural Engineering (ICEA), Italy
}

\begin{abstract}
In the manufacture of carbon steel in Spain and Italy, there is a prevalent process known as "the electric cycle", which involves melting scrap in an Electric Arc Furnace (EAF) and then refining the steel in a Ladle Furnace (LF). In this process, the main residues generated are two types of slag: the EAF Slag and the LF Slag. The excellent properties of EAF slag are well known and guarantee its successful use as a coarse aggregate in the manufacture of bituminous mixtures. On the other hand, research and application concerning the use of LF slag in asphalt mixtures are still at an early stage notwithstanding such slag has appropriate particle size and promising chemical features to be used as fine aggregate and/or filler. In this research, a rational approach to manufacturing dense graded asphalt concrete exclusively with steel slag aggregates is developed, not using any natural aggregate and thus providing sustainable (and high-performance) asphalt mixes. The design of this mix involves using EAF slag as coarse aggregate and LF slag as fine aggregate and filler. A laboratory test program was organized to accomplish this objective based on the evaluation of different bituminous mixtures incorporating these slags. Such mixtures were designed according to the Marshall procedure and then compared with a reference material (manufactured with conventional aggregates). In particular, natural filler, fine aggregate and coarse aggregate of the reference mixture were progressively replaced by the corresponding slag in order to highlight the contribution of the different fractions. The laboratory study was carried out by performing different tests analysing mechanical behaviour, durability and moisture susceptibility. The results arising from this preliminary research show that, although some refining may be done in the mix design, a sustainable asphalt concrete manufactured entirely with steel slag aggregates can be successfully achieved.
\end{abstract}

Keywords: EAF steel slag, ladle furnace slag, asphalt mixtures, mix design, laboratory study

\section{Introduction}

The new production context of the $21^{\text {st }}$ century, which began with the development of "from cradle to cradle" and "blue economy" philosophies, and which in recent years has been closing ranks around the concept of the "Circular Economy", has had a high impact on the European Union. This has also been reflected in the priorities of the H2020 programmes and will continue to be one of the key points on the European Union's Research Agenda. One of the main topics of the Circular Economy is the one that promotes reusing and recycling waste streams and aims to transform $100 \%$ of the waste into a resource, which is known as the 
"zero waste" policy. Within the construction industry, which is one of the major consumer of resources, this trend is reflected in the "sustainable construction", with big efforts to reuse by-products and wastes and minimize landfilling. But this practice has an intrinsic need for scientific support to facilitate this reuse, combining sustainability and compliance with technical requirements.

In a continuously growing trend, in 2016 the global steel industry produced 1.6 billion tons of steel [1] and Europe manufactured 162 Mtons [2]. Steel is an extremely recyclable product and has an industry very committed to the life-cycle standard [3]. However, during its productive process, a series of wastes are generated that the industry is fighting to turn into valuable resources. Steel slag is the main by-product of the metallurgical industry. The electric cycle is the most prevalent production process in Spain and Italy, and mainly involves two phases: melting recycled scrap into an Electric Arc Furnace (EAF), and then refining the steel through a Ladle Furnace (LF). This process generates over 10 million tons of slag per year in Europe [4]. The EAF slag (EAFS), produced during the primary metallurgy, has a longer history of research and execution of construction materials and other industrial activities, as quality aggregate. It has traditionally been used as unbound material in granular layers of transportation infrastructures [5-7] due to its wear resistance, hardness and angularity. Moreover, EAF slag provides a high quality aggregate for bituminous mixtures $[8,9]$ thank to its remarkable polishing and fragmentation resistance. EAFS is being also introduced in the manufacture of hydraulic concrete as coarse and fine aggregate $[10,11]$ leading to good compressive strength and tensile strength and similar durability to conventional materials.

The reuse of the LF slag (LFS), the by-product from the refining of steel, is less widespread. One of the main properties of LFS is its hydraulicity, resulting from its chemical composition, which provides it with cementitious properties $[12,13]$. Based on this, LFS may be an active or inert addition in the preparation of Portland cement clinker [12-14]. Within the construction industry, these cementitious properties and their initial possibilities are being explored, mostly to replace cement or lime in varied applications such as mortars [12-14] and concrete $[15,16]$, soil stabilization $[17,18]$ and landfill covers [19], among others.

Despite the above-mentioned, there is still an important excess of both slags, and a significant amount of them is dumped at landfill sites, with its consequent environmental and visual impacts. This prompts a search for new alternatives to reduce this volume of waste and undesired landfilling.

\section{Objective and research approach}

The introduction of LFS in bituminous mixtures is still in very early stages [20]. It is necessary to validate its use as a fine material with guarantees that allow its safe use. The complementarity of the particle size of both slags (EAFS and LFS) would allow an integral use of these by-products obtained from the same industrial process. Combining the experimental use of the Ladle Furnace slag as fine aggregate and filler with the proven use of EAF slag as a quality coarse aggregate would allow producing bituminous mixtures without using any natural aggregate, creating a new generation of totally sustainable mixtures.

Thus, the aim of this research is to study the effects of the progressive introduction of LFS and EAFS into asphalt concretes in order to study the final possibility of making a mixture manufactured entirely with steel aggregates.

\section{Materials and methods}

\subsection{Materials and specimen preparation}

All the tested materials were prepared using a Polymer Modified Bitumen, classified as PMB 45/80-60 according to EN 14023. The reference mixtures were manufactured using siliceous 
natural aggregates from a Spanish quarry as coarse and fine fractions (Table 1). Such reference mixes used ordinary Portland cement CEM I/42.5 R as filler.

The slag mixes were prepared by progressively replacing natural filler, fine aggregate and coarse aggregate of the reference mixture with the corresponding slag fraction. The Ladle Furnace Slag (LFS), a greyish-white powdery material (0/2 $\mathrm{mm}$ particle size), was used as filler and fine aggregate whereas the Electric Arc Furnace Slag (EAFS), a blackish grey aggregate (2/16 mm particle size) with small inclusions of metallic particles, was used as coarse fraction (Tables 1 and 2). Specimens were manufactured according to EN 12697-35 and compacted according to the Marshall procedure (EN 12697-30).

Table 1 Physical properties of the siliceous aggregate and the slags

\begin{tabular}{lllll}
\hline Feature & Standard & Silice & EAFS & LFS \\
\hline Bulk density & EN 1097-6 & $2.74 \mathrm{~g} / \mathrm{cm}^{3}$ & $3.60 \mathrm{~g} / \mathrm{cm}^{3}$ & $2.83 \mathrm{~g} / \mathrm{cm}^{3}$ \\
\hline Fineness modulus & EN 933-1 & 2.9 & - & 4.2 \\
\hline Blaine specific surface & EN 196-6 & - & - & $2654-3091 \mathrm{~cm}^{2} / \mathrm{g}$ \\
\hline Sand equivalent & EN 933-8 & $78 \%$ & $98 \%$ & $50 \%$ \\
\hline Water absorption & EN 1097-6 & $1.5 \%$ & $2.1 \%$ & \\
\hline Los Angeles coefficient & EN 1097-2 & $23 \%$ & $21 \%$ & - \\
\hline Polished stone value & EN 1097-8 & $52 \%$ & $56 \%$ & - \\
\hline
\end{tabular}

Table 2 Main chemical composition of the EAFS and LFS used

\begin{tabular}{lllllll}
\hline Component & $\mathrm{CaO}$ & $\mathrm{SiO}_{2}$ & $\mathrm{MgO}$ & $\mathrm{Al}_{2} \mathrm{O}_{3}$ & $\mathrm{Fe}_{2} \mathrm{O}_{3}$ & $\mathrm{MnO}$ \\
\hline EAFS [wt.-\%] & 27.7 & 19.1 & 2.5 & 13.7 & 26.8 & 5.3 \\
\hline LFS [wt.-\%] & 56.7 & 17.7 & 9.6 & 6.6 & 2.2 & 0.3 \\
\hline
\end{tabular}

\subsection{Mix design and tested mixtures}

The grading curve of the mixtures was selected as mid-band of the mixture AC16D chosen from the Spanish standard PG-3 [21] (Table 3). The AC16D is a dense graded asphalt mixture with a nominal maximum size of $16 \mathrm{~mm}, 4.5 \%$ of minimum bitumen content and voids from 4 to 6 $\%$; particularly indicated for surface layers.

Table 3 Grading envelope AC16D from the PG-3 [21]

\begin{tabular}{lllllllll}
\hline Sieve size [mm] & 22 & 16 & 8 & 4 & 2 & 0.5 & 0.25 & 0.063 \\
\hline Mass passing [\%] & 100 & $90-100$ & $64-79$ & $44-59$ & $31-46$ & $16-27$ & $11-20$ & $4-8$ \\
\hline
\end{tabular}

The Marshall procedure was used for determining the optimal bitumen content (OBC) with a compaction grade of 75 blows per face of the specimen, according to the PG-3 specifications. Four bitumen contents were investigated (4.5-5.0-5.5-6.0\%) by testing three samples for each bitumen content. Volumetric properties were analyzed before carrying out the Marshall tests (EN 12697-34) and the OBC was established maximizing the Marshall Stability in the range in which the air voids content complies with the specification.

Four types of mixes were manufactured (Table 4). The first one is the "control mix", fabricated with comparison purposes. Then, the LFS and the EAFS are introduced progressively, in substitution of the natural filler, fine and coarse aggregates of the reference mixture in order to highlight the contribution of the different fractions. 
Table 4 Different mixes used in the research

\begin{tabular}{lllll}
\hline & SSC & SSL & SLL & ELL \\
\hline Coarse aggregate $(>2 \mathrm{~mm})$ & Siliceous & Siliceous & Siliceous & EAFS \\
\hline Fine aggregate $(2-0.0063 \mathrm{~mm})$ & Siliceous & Siliceous & LFS & LFS \\
\hline Filler $(<0.0063 \mathrm{~mm})$ & Cement & LFS & LFS & LFS \\
\hline Binder & PMB & PMB & PMB & PMB \\
\hline
\end{tabular}

\subsection{Test methods}

Volumetric properties, mechanical behaviour (indirect tensile strength), moisture susceptibility and wear resistance were all tested with three specimens for each mixture at the optimum bitumen content compacted applying 50 blows per face.

The air void content (AVC) and the voids in the mineral aggregates (VMA) were determined following the EN 12697-8 Standard. To this aim, maximum density and bulk density were determined according to EN 12697-5 procedure C and EN 12697-6 procedure B, respectively. The mechanical behavior of the mixes was assessed in terms of the indirect tensile strength (ITS) of the cylindrical samples as described in the EN 12697-23.

Raveling resistance was studied through the Cantabro test (EN 12697-17) that evaluates particle loss (PL) of a specimen placed inside the Los Angeles drum and operated for 300 revolutions without steel balls.

According to EN 12697-12, the moisture susceptibility was evaluated through the Indirect Tensile Strength Ratio (ITSR) calculated as the percentage ratio between the Indirect Tensile Strength of wet and dry conditioned specimens. Water conditioning was carried out according to the abovementioned EN 12697-12, i.e. subjecting the samples to water submersion at 40 ${ }^{\circ} \mathrm{C}$ for 72 hours.

\section{Results and analysis}

\subsection{Mix design}

For all the mixtures studied, the maximum values of the stability were placed in the interval between 4.5 and $5.0 \%$ of bitumen content. Within this range, as expected, the higher the bitumen content, the lower the voids. Moreover, when increasing the bitumen content over $5 \%$, the slag mixtures voids trend levelled out to the same value. The VMA also presented their descending branch in this interval. Based on all the considerations described above, $5 \%$ bitumen content by weight of the aggregates was selected as OBC for all the mixtures.

\subsection{Volumetric properties}

Experimental results presented in Table 5 clearly show that the introduction of LFS as fine aggregate led to unacceptable voids (even higher than $10 \%$ ). This is probably due not only to the higher angularity of the LFS aggregates but especially to an excessive stiffening effect of the LFS aggregate on the asphalt mortar that negatively affect the mixing and compaction with the consequent voids problem.

As shown in the following paragraphs, this fact really affects all the other properties analysed, even if in most of the cases the performances achieved are still acceptable but lower than those of the reference mixture. 


\subsection{ITS}

The best ITS results were achieved when the LFS was used as filler combined with siliceous aggregates as fine and coarse aggregates, whereas lower performances are attained when using EAF slags within the aggregate matrix (Table 5).

The LFS used as filler produced an improved mechanical behaviour, probably due to the enhanced rheological properties of the bituminous mastic that is the main responsible for tensile failures of the bituminous mixtures. Conversely, the use of slags as fine and coarse aggregate led to a worsening on the ITS. This was likely due to the higher voids content that surely weaken the mixtures rather than a real detrimental effect on the tensile resistance of the materials. In any case, the results can be considered acceptable for all the mixtures if compared to usual requirements of technical specifications.

Table 5 Test results summary

\begin{tabular}{lllll}
\hline & $\begin{array}{l}\text { AVC } \\
{[\%]}\end{array}$ & $\begin{array}{l}\text { ITS } \\
{\left[\mathrm{N} / \mathrm{mm}^{2}\right]}\end{array}$ & $\begin{array}{l}\text { PL } \\
{[\%]}\end{array}$ & ITSR \\
\hline SSC & 5.7 & 1.84 & 7.7 & 0.93 \\
\hline SSL & 6.7 & 2.26 & 7.3 & 0.80 \\
\hline SLL & 10.8 & 1.49 & 18.7 & 0.77 \\
\hline ELL & 11.9 & 1.46 & 14.8 & 0.69 \\
\hline
\end{tabular}

\subsection{Cantabro}

Again, the mixture made with LFS as filler presents the best results in terms of particle loss, even better than the control mix, meaning that the ladle slag produce a high-quality mastic with the binder that guarantees a stronger film of bitumen covering the grains protecting them from the risk of disintegration.

Contrariwise, the mixtures SLL and ELL present worse response, which can be explained by the really higher void content that makes them more prone to ravelling. Literature demonstrates a clear direct correlation between the air void content and the corresponding abrasion resistance [22]. Finally, the use of EAFS as a coarse aggregate returns a significant better response than that of the corresponding SLL mixture having siliceous coarse aggregates; which may be due to a greater adhesion between EAF and bitumen.

Also in this case, the results can be considered acceptable for all the mixtures if compared to $20 \%$ of particle loss, which is a common limit for heavy traffics [21].

\subsection{ITSR}

From Table 5, it can be noted that the control mix (SSC) gives the best results in terms of ITSR. This suggests that a lower affinity between steel slags and bitumen exists in the case of water presence. Among the slag mixtures, only the SSL presents an acceptable ITSR, even if similar results are also attained by SLL. This is probably related to the affinity between the asphalt mastic and the coarse aggregates. In fact, ELL mix prepared with EAF coarse aggregates exhibited the worse performances with a poor ITSR.

However, also in this case, a major role is also played by the higher voids content of SLL and ELL mixtures that sensibly contribute to the moisture resistance of an asphalt concrete. 


\section{Conclusions}

Based on the results arising from this preliminary investigation concerning the feasibility of preparing asphalt mixtures only containing steel slag aggregates (including ladle furnace slag as filler and fine aggregates), the following basic conclusions can be drawn:

- The air void content of the mixtures made with LFS slag as fine aggregate is excessive. This is probably due to the stiffening effect of LFS into the asphalt mortar making the mixing and compaction difficult;

- The tensile strength and raveling resistance were excellent for the mixture with LFS only as filler, due to the enhanced rheological properties of the bituminous mastic which enables this mixture to be used in the most demanding applications. On the other hand, the excessive void content of the other slag mixtures led to worse mechanical performance (even if still acceptable);

- Moisture susceptibility in term of ITSR confirmed that the control mix has the lower sensitivity to damage suggesting that a lower affinity between slags and bitumen exists in the case of water presence. The too high air void content achieved when adding LFS as fine aggregate inevitably led to worse performances with not acceptable ITSR values.

Further research is needed to overcome the issues related to the low compactability of the mixtures prepared using LFS as fine aggregate. Experimental studies are currently in progress in this sense by adopting different production temperatures and/or bitumen grade.

\section{References}

[1] World Steel Association. Available from: https://www.worldsteel.org/.

[2] The European Steel Association. Available from: http://www.eurofer.org/.

[3] Reh, L.: Process engineering in circular economy. Particuology, 2013. 11(2): pp. 119-133.

[4] EUROSLAG, Position Paper on the Status of Ferrous Slag. 2013, The European Slag Association: Germany.

[5] Motz, H., Geiseler, J.: Products of steel slags an opportunity to save natural resources. Waste Management, 2001. 21(3): pp. 285-293.

[6] Rohde, L., Nunez, W.P., Ceratti, J.A.P.: Electric Arc Furnace Steel Slag: Base Material for Low-Volume Roads, in Transportation Research Record. 2003: Reno, NV. pp. 201-207.

[7] Pasetto, M., Baliello, A., Giacomello, G., Pasquini, E.: Sustainable solutions for road pavements: A multi-scale characterization of warm mix asphalts containing steel slags. Journal of Cleaner Production, 2017. 166: pp. 835-843.

[8] Emery, J.J.: Steel Slag utilization in asphalt mixes. in Canadian Technical Asphalt Association Proceedings. 1984. National Slag Association.

[9] Pasetto, M., Baldo, N.: Mix design and performance analysis of asphalt concretes with electric arc furnace slag. Construction and Building Materials, 2011. 25(8): pp. 3458-3468.

[10] Manso, J.M., Gonzalez, J.J., Polanco, J.A.: Electric arc furnace slag in concrete. Journal of Materials in Civil Engineering, 2004. 16(6): pp. 639-645.

[11] Pellegrino, C., Gaddo, V.: Mechanical and durability characteristics of concrete containing EAF slag as aggregate. Cement and Concrete Composites, 2009. 31(9): pp. 663-671.

[12] Adolfsson, D., Engstrom, F., Robinson, R., Bjorkman, B.: Cementitious phases in ladle slag. Steel Research International, 2011. 82(4): pp. 398-403.

[13] Papayianni, I., Anastasiou, E.: Effect of granulometry on cementitious properties of ladle furnace slag. Cement and Concrete Composites, 2012. 34(3): pp. 400-407. 
[14] Herrero, T., Vegas, I.J., Santamaria, A., San-Jose, J.T., Skaf, M.: Effect of high-alumina ladle furnace slag as cement substitution in masonry mortars. Construction and Building Materials, 2016. 123: pp. 404-413.

[15] Polanco, J.A., Manso, J.M., Setien, J., Gonzalez, J.J.: Strength and durability of concrete made with electric steelmaking slag. ACI Materials Journal, 2011. 108(2): pp. 196-203.

[16] Manso, J.M., Hernandez, D., Losanez, M.M., Gonzalez, J.J.: Design and elaboration of concrete mixtures using steelmaking slags. ACI Materials Journal, 2011. 108(6): pp. 673-681.

[17] Manso, J.M., Ortega-Lopez, V., Polanco, J.A., Setien, J.: The use of ladle furnace slag in soil stabilization. Construction and Building Materials, 2013. 40: pp. 126-134.

[18] Ortega-Lopez, V., Manso, J.M., Cuesta, I.I., Gonzalez, J.J.: The long-term accelerated expansion of various ladle-furnace basic slags and their soil-stabilization applications. Construction and Building Materials, 2014. 68: pp. 455-464.

[19] Herrmann, I., Andreas, L., Diener, S., Lind, L.: Steel slag used in landfill cover liners: Laboratory and field tests. Waste Management and Research, 2010. 28(12): pp. 1114-1121.

[20]Skaf, M., Ortega-Lopez, V., Fuente-Alonso, J.A., Santamaria, A., Manso, J.M.: Ladle furnace slag in asphalt mixes. Construction and Building Materials, 2016. 122: pp. 488-495.

[21] PG-3 Pliego de Prescripciones Técnicas Generales para Obras de Carreteras y Puentes, PG-3 (General Technical Specifications in Road Construction) Spanish Ministry of Public Works.: Madrid.

[22] Frigio, F., Pasquini, E., Ferrotti, G., Canestrari, F.: Improved durability of recycled porous asphalt. Construction and Building Materials, 2013. 48: pp. 755-763. 
